\title{
The oldest platylepadid turtle barnacle (Cirripedia, Coronuloidea): a new species of Platylepas from the Lower Pleistocene of Italy
}

\author{
Alberto COLLARETA ${ }^{1, *}$, Agatino REITANO ${ }^{2},{\text { Antonietta } \text { ROSSO }^{3} \text {, Rossana SANFILIPPO }}^{4}$, \\ Mark BOSSELAERS ${ }^{5}$, Giovanni BIANUCCI ${ }^{6}$ \& Gianni INSACCO $^{7}$ \\ ${ }^{1,6}$ Dipartimento di Scienze della Terra, Università di Pisa, Via Santa Maria 53, 56126 Pisa, Italy. \\ ${ }^{2,7}$ Museo Civico di Storia Naturale di Comiso, Via degli Studi 9, 97013 Comiso, Italy. \\ ${ }^{3,4}$ Dipartimento di Scienze Biologiche, Geologiche e Ambientali, \\ Università di Catania, Corso Italia 57, 95129 Catania, Italy. \\ ${ }^{5}$ Koninklijk Belgisch Instituut voor Natuurwetenschappen, Operationele Directie Aarde en \\ Geschiedenis van het Leven, Vautierstraat 29, Brussel, Belgium; Koninklijk Zeeuwsch Genootschap \\ der Wetenschappen, P.O. Box 378, 4330 AJ Middelburg, the Netherlands.
}

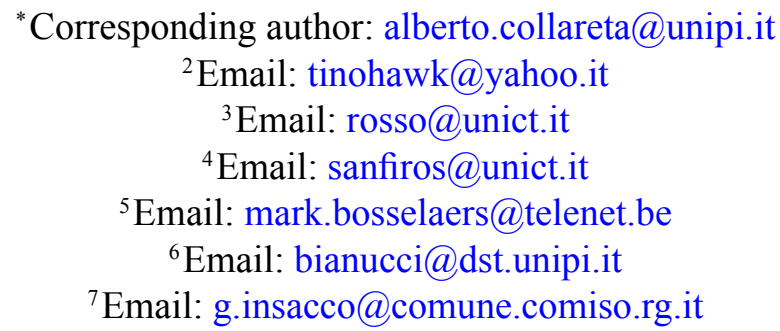

\footnotetext{
${ }^{1}$ urn:1sid:zoobank.org:author:85C5A7BC-5E01-4DBC-87B8-3B1D265C4A98

${ }^{2}$ urn:lsid:zoobank.org:author:31BBE4B7-06E9-4B9D-BE39-4892E7D5F66C

${ }^{3}$ urn:1sid:zoobank.org:author:89380E8D-2532-4108-B37A-A4DC56271B4E

${ }^{4}$ urn:lsid:zoobank.org:author:E5633ADB-A74F-40E0-9DDC-207388E38BDE

${ }^{5}$ urn:1sid:zoobank.org:author:F1D0BDE5-8671-4C42-8995-6449788EA562

${ }^{6}$ urn:Isid:zoobank.org:author:50084CA2-49E0-4B21-B479-07B70135C8F5

${ }^{7}$ urn:lsid:zoobank.org:author:507778EA-45F1-41A7-B9DF-09F138DDA99F
}

\begin{abstract}
Coronuloid barnacles are epibionts of several marine vertebrates (including cetaceans and sea turtles) as well as invertebrates, and are assigned to two families of turtle barnacles (Chelonibiidae Pilsbry, 1916 and Platylepadidae Newman \& Ross, 1976) and one family of whale barnacles (Coronulidae Leach, 1817). Chelonibiids and coronulids have a scanty, albeit significant fossil record extending back to the Eocene and Pliocene, respectively; in turn, the fossil record of platylepadids is limited to a single record from the Upper Pleistocene. Here we report on an isolated carinolateral compartment of Platylepas Gray, 1825, the type genus of the family, from Lower Pleistocene (Gelasian) epibathyal deposits exposed at Milazzo (Sicily, Italy). This specimen is here designated holotype of a new species, $†$ Platylepas mediterranea sp. nov. We argue that, like most extant members of Platylepas, $\dagger P$. mediterranea sp. nov. lived partially embedded in the skin of a sea turtle. This record of an extinct platylepadid - the first from the Mediterranean region and the second worldwide - pushes back the fossil record of Platylepadidae to the lowermost Quaternary, thus possibly supporting an even earlier (e.g.,
\end{abstract}


Neogene) timing for the origin of this family and adding a new chapter to the evolutionary history of one of the most diverse and successful lineages of epizoic crustaceans.

Keywords. $\uparrow$ Platylepas mediterranea sp. nov., sea turtles, Mediterranean Basin, evolution, symbiosis.

Collareta A., Reitano A. Rosso A., Sanfilippo R., Bosselaers M., Bianucci G. \& Insacco G. 2019. The oldest platylepadid turtle barnacle (Cirripedia, Coronuloidea): a new species of Platylepas from the Lower Pleistocene of Italy. European Journal of Taxonomy 516: 1-17. https://doi.org/10.5852/ejt.2019.516

\section{Introduction}

Extant turtle and whale barnacles (Cirripedia Burmeister, 1834, Thoracica Darwin, 1854, Coronuloidea Leach, 1817) are epibiotic organisms that attach themselves to the external surface of several saltwater and estuarine vertebrates (including toothed and baleen whales, sea turtles, sea cows, crocodiles, snakes and bony fish) and invertebrates (including crabs, horseshoe crabs and crayfish) (Hayashi 2013, and references therein). By living on mobile host substrates, these sessile filter-feeding crustaceans can exploit a continuous flow of water laden with nutrient particles while at the same time lowering the risk of predation (Seilacher 2005). Currently, coronuloid barnacles are assigned to three families, namely Coronulidae, Chelonibiidae and Platylepadidae (Ross \& Frick 2011). Whereas coronulids are obligate phoronts of cetaceans (hence their vernacular name, whale barnacles), chelonibiids and platylepadids (collectively known as turtle barnacles) exhibit more generalist host habits, although most species live preferentially or exclusively on the skin, carapace or plastron of sea turtles. The fossil history of Chelonibiidae dates back to the Paleogene (with the earliest representative of the family, $†$ Emersonius cybosyrinx Ross in Ross \& Newman, 1967, from the upper Eocene Williston Limestone of Florida, USA), whereas coronulids seemingly appeared later, starting with $\dagger$ Coronula bifida Bronn, 1831 in a few Upper Pliocene deposits worldwide (e.g., Marquet et al. 2009). In turn, the fossil record of Platylepadidae, a widely distributed and well-diversified family of small-sized, warm-water coronuloids, with at least fourteen extant species in six genera (Ross \& Frick 2011), is much less extensive and, in fact, comprises merely the holotype of $\uparrow$ Platylepas wilsoni Ross, 1963 from the Upper Pleistocene Pamlico Formation of Florida, USA.

In the present paper we report on the presence of a member of Platylepas Gray, 1825, the type genus of the family, in Lower Pleistocene marine deposits of the central Mediterranean Basin. The single specimen known is a right carinolateral compartment; it is here designated holotype of a new species and its paleontological significance is briefly discussed.

\section{Material and methods}

The present barnacle was discovered by one of us (A.Re.) in a succession of Plio-Pleistocene marine sedimentary strata that is exposed along a coastal cliff at Cape Milazzo (Messina Province, Sicily, Italy), a peninsula located on the northeastern corner of Sicily, to the southeast of the Aeolian archipelago (Fig. 1). These deposits fill small depressions on both the underlying Paleozoic metamorphites and their Upper Miocene sedimentary cover (Fois 1990a, 1990b). These Plio-Pleistocene strata are capped by a 'Tyrrhenian' terrace that, in turn, is overlain by Holocene volcanic ashes (Fois 1990a, 1990b). In particular, the silty to sandy, carbonate-rich deposits referred to as "Marne Calcaree Gialle" (i.e., yellow calcareous marls; hereinafter: YCM) are rich in fossils of benthic invertebrates, including corals (scleractinians and octocorals), echinoderms (echinoids and comatulid crinoids), bryozoans, mollusks, crustaceans, foraminifera, serpulids and brachiopods. This fossil association is widely considered to be indicative of deposition in an epibathyal environment (Gignoux 1913; Lipparini et al. 1955; Mars 1956; Gaetani \& Saccà 1984; Gaetani 1986; Violanti 1988; Langer 1989; Palazzi \& Villari 1996; Rosso 2002a, 2002b, 2005; Sciuto 2003, 2005, 2009, 2012a, 2012b, 2014; Pasini \& Garassino 2011; Rosso \& Braga 
2013; Borghi et al. 2014; Rosso \& Di Martino 2015). The specimen described herein was collected from the Cala S. Antonino outcrop (approximate coordinates $38^{\circ} 15^{\prime} 54.9^{\prime \prime} \mathrm{N}, 15^{\circ} 14^{\prime} 12.7^{\prime \prime}$ E, see Fig. 1), where the YCM reaches a maximum thickness of 13.5 meters. These strata are Early Pleistocene in age, being largely attributable to the Gelasian and, with respect to their uppermost few decimetres, to the Calabrian (Rosso et al. 2012, and references therein). The platylepadid compartment, recovered from the Gelasian portion of this YCM succession, is now housed in the collections of the Museo Civico di Storia Naturale di Comiso (MSNC, Comiso, Ragusa Province, Sicily, Italy). The specimen was examined and photographed using backscattered electrons under an LMU Tescan Vega II Scanning Electron Microscope (SEM) at the Università di Catania (Sicily, Italy). The following symbols and anatomical abbreviations are utilized throughout the text:

$$
\begin{aligned}
\dagger & =\text { extinct species } \\
\mathrm{R} & =\text { rostrum } \\
\mathrm{RL} & =\text { rostrolateral plate }
\end{aligned}
$$

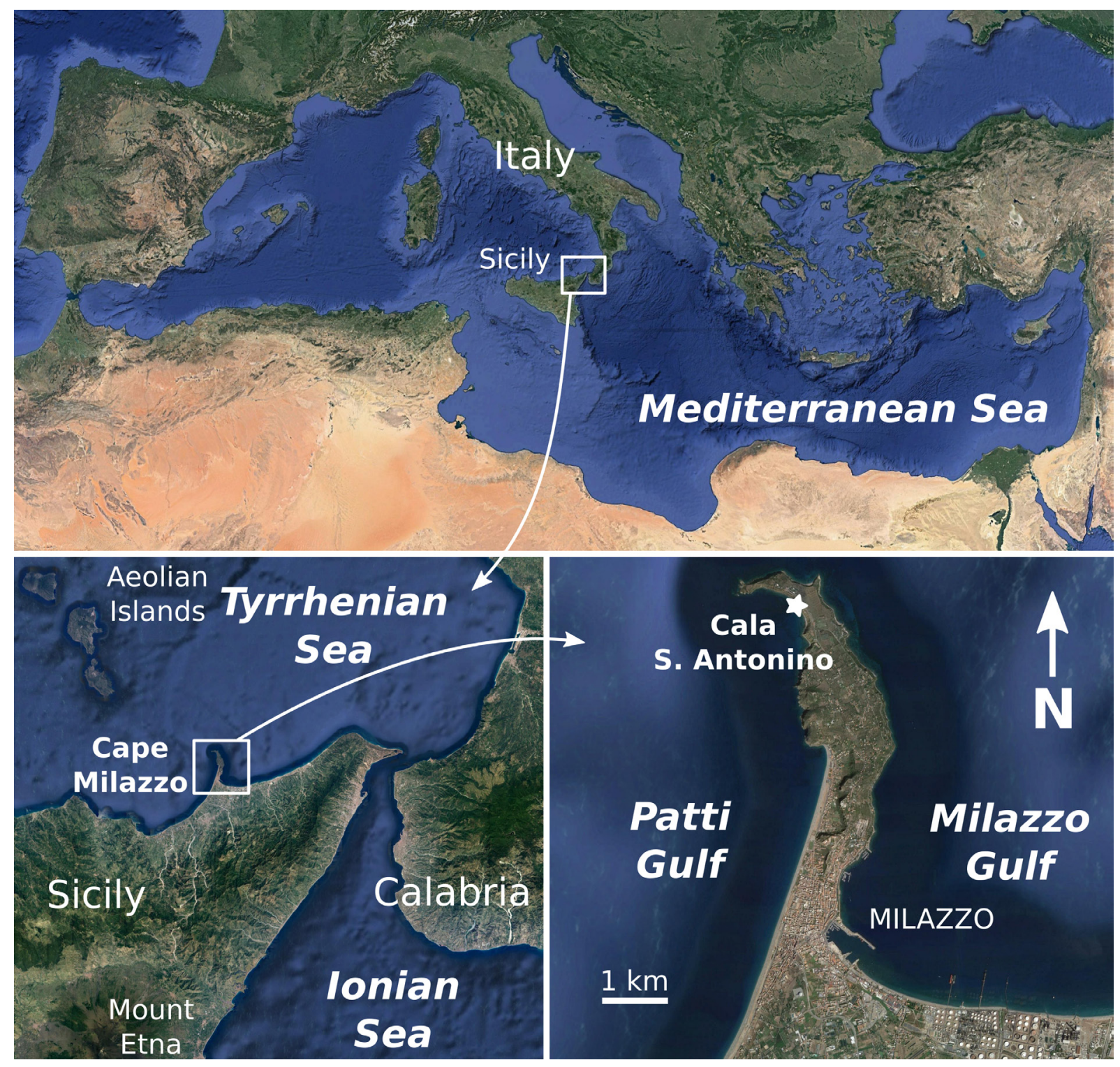

Fig. 1. Locality map, showing provenance (white star) of the holotype of the new platylepadid (MSNC 4562) described herein. All images from Google Earth. 


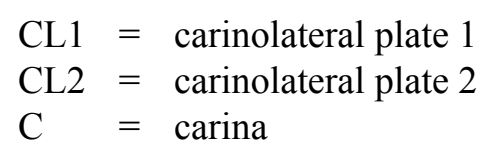

\section{Results}

Class Maxillopoda Dahl, 1956

Subclass Cirripedia Burmeister, 1834

Superorder Thoracica Darwin, 1854

Order Sessilia Lamarck, 1818

Suborder Balanomorpha Pilsbry, 1916

Superfamily Coronuloidea Leach, 1817

Family Platylepadidae Newman \& Ross, 1976

Diagnosis (after Ross \& Frick 2011: 62)

Wall six-plated (R-CL1-CL2-C) or eight-plated in juvenile specimens (R-RL-CL1-CL2-C); relatively thin; parietes each with midrib and/or tooth; longitudinal tubes when present external (internal in Chelolepas); apertural hood absent (except in Chelolepas); primary or internal lamina (including the sheath) solid, outer lamina (when present) formed by joining of longitudinal T-shaped flanges extending from inner wall, thus forming external longitudinal canals.

\section{Included subfamilies}

Platylepadinae Newman \& Ross, 1976; Calyptolepadinae Frick, Zardus \& Lazo-Wasem, 2010; Chelolepadinae Frick \& Ross, 2011; Cylindrolepadinae Frick \& Ross, 2011; Stomatolepadinae Frick \& Ross, 2011.

\section{Subfamily Platylepadinae Newman \& Ross, 1976}

Diagnosis (emended after Ross \& Frick 2011: 62)

Wall peltate or low-conical; mono- or bi-lamellar; parietes with a large internal midrib either with or without a corresponding external medial sulcus; midrib either smooth or having several alternating ridges incorporated into basal surface; external longitudinal sulci, when present, formed by T-shaped flanges; sutural elaborations absent; orifice worn by corrosion or abrasion, or dehiscent.

\section{Included genus}

Platylepas Gray, 1825.

\section{Genus Platylepas Gray, 1825}

\section{Diagnosis}

As for the subfamily, until new genera are referred here.

\section{Type species}

Lepas hexastylos Fabricius, 1798, by the subsequent designation of Pilsbry (1916: 264).

\section{Included species}

Platylepas hexastylos; P. decorata Darwin, 1854; P. ophiophila Lanchester, 1902; P. indicus Daniel, 1958; $\uparrow$ P. wilsoni Ross, 1963; P. coriacea Monroe \& Limpus, 1979; $\uparrow P$. mediterranea sp. nov. 


\section{Remarks}

Following Utinomi (1970) and Hayashi (2013), we consider Cryptolepas ophiophilus Krüger, 1912 (= Platylepas krügeri sensu Pilsbry 1916) to be a junior synonym of Platylepas ophiophila. Moreover, we concur with various authors (e.g., Monroe \& Limpus 1979; Ross \& Frick 2011; Hayashi 2013) in regarding Platylepas multidecorata Daniel, 1962 as a junior synonym of Platylepas decorata Darwin, 1854.

\section{Range and distribution}

Early Pleistocene (Gelasian) to Recent. Recorded as fossil from the Lower Pleistocene (Gelasian) of Sicily, southwest Italy (present paper) and the Upper Pleistocene of Florida, southeastern USA $(\dagger P$. wilsoni). Currently known as an epizoic phoront found on several marine vertebrates (such as turtles, sea snakes, sirenians and fish) occurring in tropical and warm-temperate seas (between ca $45^{\circ} \mathrm{N}$ and ca $45^{\circ} \mathrm{S}$ latitude).

\section{$\uparrow$ Platylepas mediterranea sp. nov. urn:1sid:zoobank.org:act:B197B06B-33A0-4E86-B229-5B5AFAF86E48}

Figs $1-3$

\section{Diagnosis}

Wall truncated conical; bi-lamellar; transverse growth lines forming principal sculpture of outer face of compartments; longitudinal septa and canals visible through outer wall, becoming more numerous peripherally; carinolatus three-lobed; sheath extending for less than half of total height of compartment, appressed, not hollowed out from behind, exhibiting distinct transverse grooves; accessory ribs present, corresponding to distinct sulci on outer face of compartments; inner face of compartments smooth, devoid of ridges or septa; radii narrow, sub-straight, and relatively robust; alae thin; inter-compartmental ornamentation absent.

\section{Etymology}

From Mare Mediterraneum, the Latin name of the Mediterranean Sea, in allusion to the region where the holotype was found.

\section{Material examined}

\section{Holotype}

SICILY - a single right carinolateral compartment (CL1 or CL2); Cala S. Antonino, Cape Milazzo Peninsula; 38 $15^{\prime} 54.9^{\prime \prime} \mathrm{N}, 15^{\circ} 14^{\prime} 12.7^{\prime \prime}$ E; epibathyal deposits ("Marne Calcaree Gialle"); Lower Pleistocene (Gelasian); sole known specimen to date; MSNC 4562.

\section{Description}

MSNC 4562 is an isolated, ca $7 \mathrm{~mm}$ tall, near-complete right carinolateral compartment (CL1 or CL2), the external surface of which has been moderately decorticated by wear (Fig. 2a). For this reason, we describe it here starting from the better-preserved and more informative internal surface (Fig. 2b).

When viewed internally, MSNC 4562 exhibits a rather short sheath, extending for less than half of the total height of the compartment (Fig. 2b). The sheath is strongly appressed, i.e., it runs subparallel to the external face of the compartment; its median portion bears a low and broad longitudinal ridge which corresponds to the location of the upper part of the midrib prop (see below). The sheath exhibits a few distinct plicae (here interpreted as growth lines) that extend subparallel to the gently curved (i.e., slightly S-shaped) basal margin of the sheath (Figs 2b, 3a). The fossa for the accommodation of the ala 
(hereinafter referred to as the alar depression) is shallow and its margin is rounded and roughly J-shaped. A few very weak, transversely oriented grooves are observed also within the alar depression. The sheath is massive and not hollowed out from behind. However, a very shallow depression is seen beneath the basal margin of the sheath on the radial side of the midrib prop; conversely, at the alar side of the midrib prop the sheath is solidly filled from behind, and its basal margin is just marked by a horizontal ridge forming a sort of "step" on the inner surface of the compartment (Figs 2b, 3a). Below the sheath, the inner surface of the compartment is strongly folded inwards, thus generating a prominent longitudinal midrib prop (Figs $2 \mathrm{~b}-\mathrm{f}, 3 \mathrm{a}$ ). This hook-like structure distinctly projects inwards and downwards; it is not filled internally. The transverse section of the midrib prop is roughly drop-shaped (Fig. 3f). The midrib prop runs closer to the alar margin of the compartment than to its radial margin. Therefore, it divides the inner surface of the compartment below the sheath into two areas: the smaller one is distinctly concave and roughly shaped as a longitudinally-elongated semi-cylinder; the larger one is laterally bounded by the sutural edge of the radius (Fig. 2b, f), with a broad accessory fold parallel to the midrib prop. This accessory fold is directed downwards and starts a couple of millimeters below the basal margin of the sheath (Figs 2b, 3a). No longitudinal septa occur below the sheath, either close to its base or at the periphery (i.e., close to the preserved portions of the basal margin of the compartment), as this portion of the inner surface is substantially smooth.

On the external surface of the compartment, the midrib prop and the accessory fold correspond to two shallow, yet obvious sulci which distinguish three longitudinally-elongated lobes (Fig. 2a). Although MSNC 4562 is moderately eroded externally, its trilobate aspect is well recognized from the apex of the compartment downwards (Fig. 2e). The external surface of the compartment is ornamented by longitudinal septa, which define longitudinally elongated tubes or canals between them. MSNC 4562

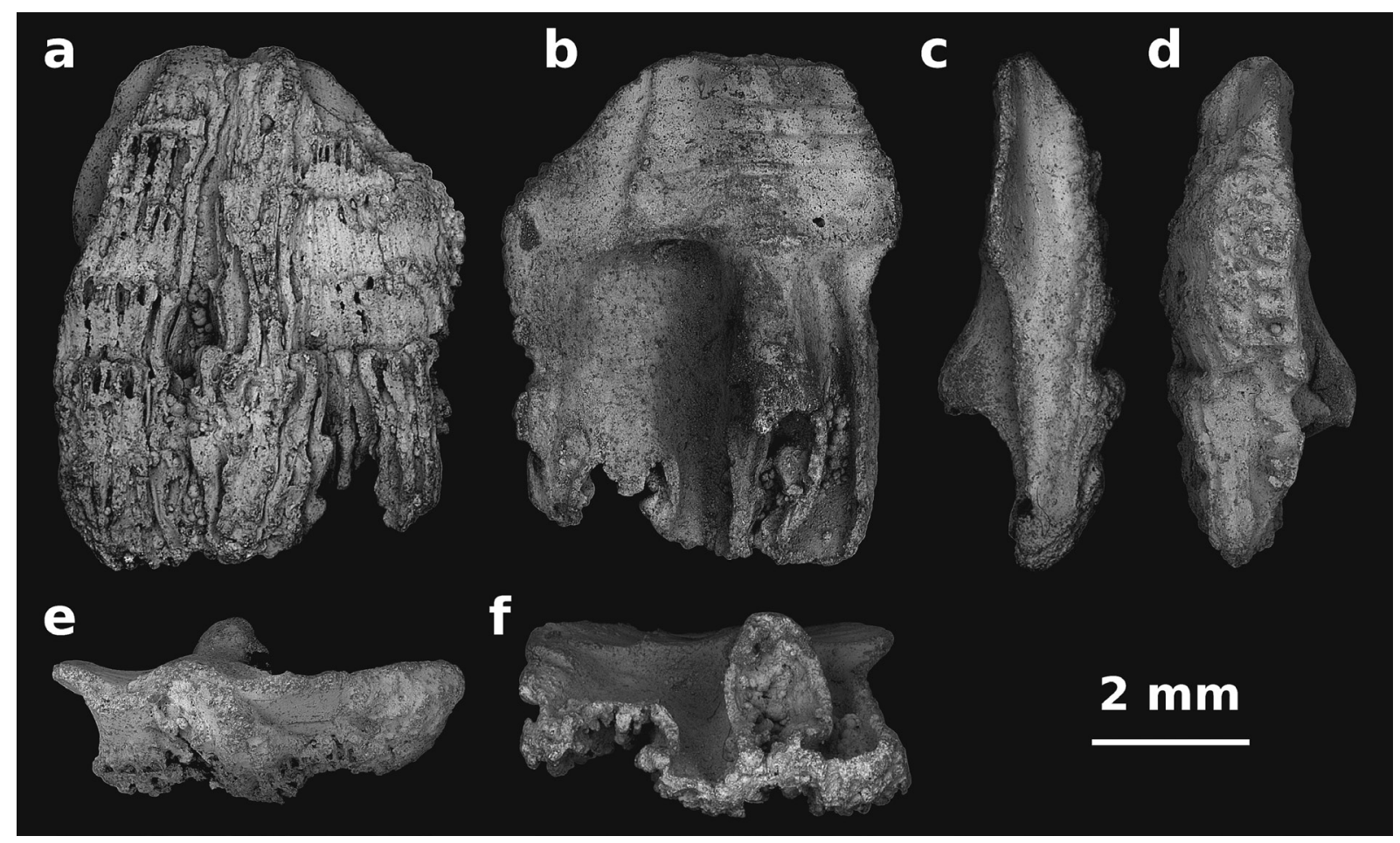

Fig. 2. †Platylepas mediterranea sp. nov., holotype, single right carinolateral compartment (CL1 or CL2) collected at Cala S. Antonino (Cape Milazzo, Sicily, southern Italy) from Lower Pleistocene (Gelasian) deposits (MSNC 4562). a. Outer view. b. Inner view. c. Alar view. d. Radial view. e. Apical view. f. Basal view. 
is therefore tubiferous and bi-lamellar, the outer lamina being produced by the distal coalescence of the septa that extend from the inner wall. However, due to overall abrasion of the terminal T-shaped flanges of the longitudinal septa, a pristine outer wall is only locally preserved (Fig. 3b). Some septa bifurcate downwards so that the interseptal distance remains roughly constant along the whole height of the compartment. This septate sculpture is affected by prominent transverse growth ridges along which the external surface of the compartment widens distinctly (Fig. 2a, c-d). The intersection of the longitudinally elongated septa and the transversely oriented growth ridges is occasionally marked by small knobs on what remains of the outer lamina (Figs 2a, 3b).

The radius is rather narrow and partially preserved. In radial view, it is sub-straight (Fig. 2d) and its basal termination weakly projects inwards. The sutural edge of the radius is relatively robust. The denticulation pattern of the sutural edge is largely eroded; where it is preserved, it appears simple, being in fact comprised of squat, blunt, transversely-oriented septa that originate from the inner margin of the radius and project outwards (Fig. 2d). The ala is thin and distally tapers moderately. The sutural edge of the alar portion of the compartment exhibits short, triangular, wedge-like complementary septa which project inwards from a main septum running along the outer margin of the compartment (Figs 2c, 3a).

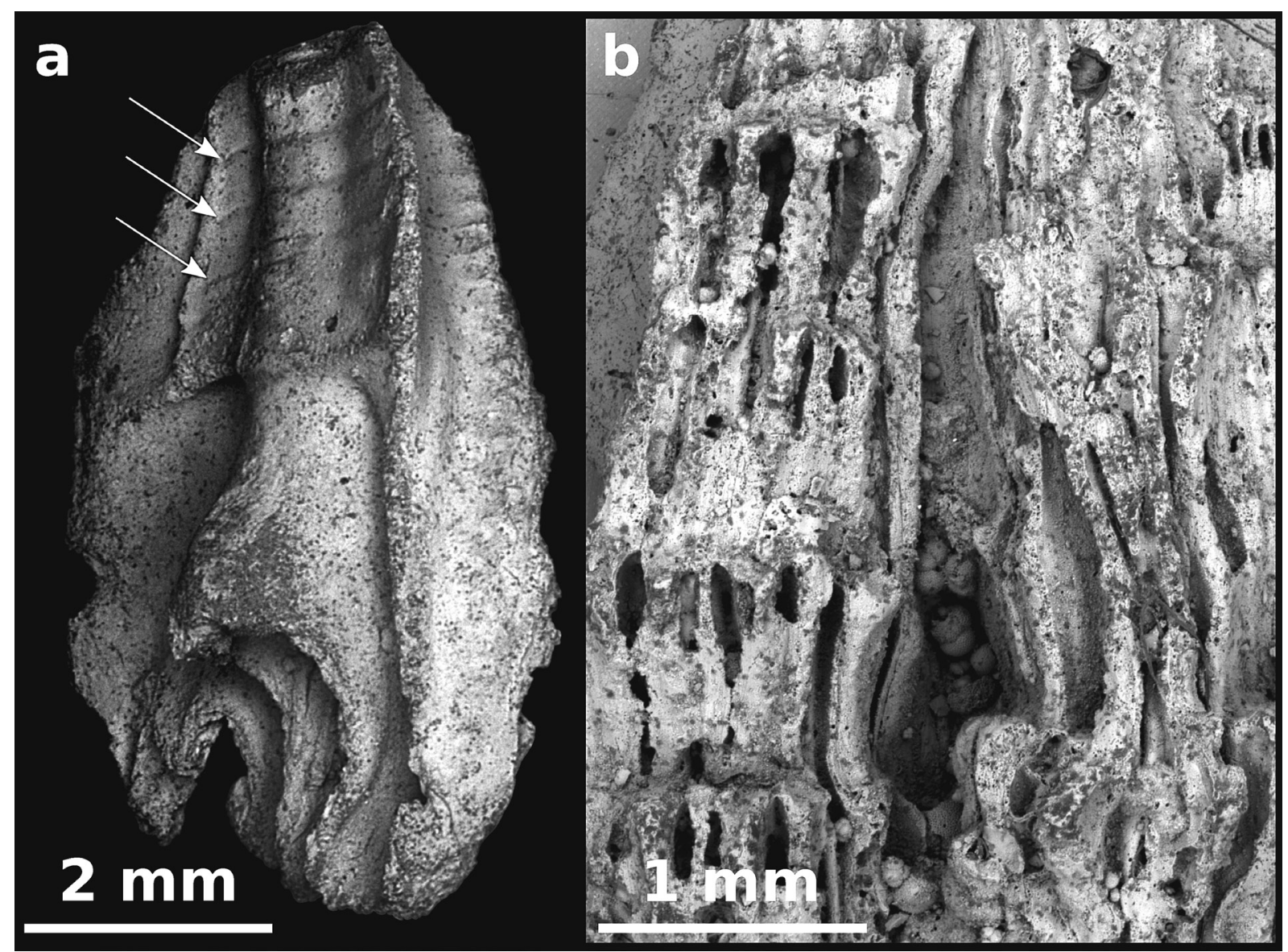

Fig. 3. †Platylepas mediterranea sp. nov., holotype (MSNC 4562). a. Interno-alar view. Note the strongly appressed sheath exhibiting distinct transverse grooves (arrows) and the short, triangular, wedge-like, transverse septa on the sutural edge of the alar portion of the compartment. b. Close-up of the outer surface of the compartment. The outer lamina is only locally preserved; where it is eroded, longitudinally elongated septa and canals are visible. The intersection between longitudinal septa and transverse growth ridges is occasionally marked by small knobs. 
Therefore, judging from the architecture of the radial and alar sutural margins, the space between two adjacent compartments would have been completely filled.

\section{Comparisons and remarks}

MSNC 4562 unambiguously belongs to the monotypical subfamily Platylepadinae based on the presence of a large and prominent midrib prop - observable on the inner surface of the compartment - which corresponds to a distinct sulcus on the external surface of the shell. The general morphology of MSNC 4562 strongly suggests a truncated conical (i.e., volcano-like) rather than peltate shell. Based on its size, a truncated conical shell that measured ca $14 \mathrm{~mm}$ in carinorostral diameter could be reconstructed; a slightly larger size estimate (ca $17 \mathrm{~mm}$ ) could be proposed if the shell were more depressed. These size estimates are largely consistent with measurements of mature specimens of extant $P$. hexastylos.

On the whole, MSNC 4562 is reminiscent of the extant species $P$. hexastylos in various aspects of the shell: the structure of the sutural margins of MSNC 4562, for instance, is rather close to that of $P$. hexastylos. In addition, the outer aspect of MSNC 4562 is similar to that of a specimen of $P$. hexastylos from Sicily as illustrated by Pilsbry (1916: pl. 67, fig. 4) and to that of numerous other truncated conical individuals of $P$. hexastylos in which the outer lamina is partially or mostly worn out, thus revealing the septate, bi-lamellar nature of the compartment wall (e.g., Darwin 1854; Pilsbry 1916; Monroe \& Limpus 1916; A.C., pers. obs.). However, various characters preserved in MSNC 4562 distinguish this fossil from the extant $P$. hexastylos. First, whereas in P. hexastylos the shell is very light and thin, MSNC 4562 appears to have been slightly more robust. Secondly, whereas in $P$. hexastylos the sheath is generally smooth and only occasionally displays weak growth lines, that in MSNC 4562 exhibits evident transverse grooves. Thirdly, in P. hexastylos the sheath is hollowed out from behind, but that in MSNC 4562 is appressed and filled from behind. Fourthly, $P$. hexastylos bears septa that extend onto the internal surface of each plate up to the level of the basal margin of the sheath or even terminate within the hollowed out portion behind the sheath; in turn, the internal surface of MSNC 4562 is devoid of septa and substantially smooth. Fifthly, whereas compartments of $P$. hexastylos appear as typically bilobate externally, the external aspect of MSNC 4562 is trilobate - a character that reflects the presence of an accessory rib on the inner surface of the compartment. Although compartments belonging to adult individuals of $P$. hexastylos occasionally exhibit an accessory rib and an incipient third lobe developing near the base of the shell, the trilobate nature of the external surface of MSNC 4562 is recognizable even close to the orifice, thus suggesting that it represents a structural character rather than an incidental feature incurred during growth. This hypothesis could find some support in the above-mentioned observation that the inner face of MSNC 4562 is smooth and devoid of those ridges and septa which in extant $P$. hexastylos aid in both fixing the phoront crustacean to its substrate and preventing the collapse of the thin barnacle shell (e.g., Ross \& Newman 1967). In this respect, the accessory rib observed in MSNC 4562 could be interpreted as a functional substitute of the fimbriated periphery of the compartments of $P$. hexastylos, substantially contributing to the stabilization of the relatively robust platylepadid shell to which MSNC 4562 belonged by providing firm anchorage to the underlying host tissue. If this interpretation is correct, a complete adult shell of the platylepadid species from Cala S. Antonino might have displayed up to 18 lobes on its external surface (e.g., three lobes on each CL, four on R, and two on C).

The extant species Platylepas coriacea, $P$. indicus and $P$. ophiophila are similar to $P$. hexastylos in shell shape and structure. MSNC 4562 further differs from $P$. coriacea by its narrower radius, longer sheath, and the trapezoidal (rather than near-triangular) outline of the paries. It differs from $P$. indicus, in which both sides of the midrib prop of each compartment bear a distinct ridge, and from P. ophiophila by not displaying three or more secondary ribs lateral to the midrib prop.

MSNC 4562 resembles P. decorata as its sheath is not hollowed out from behind and in lacking longitudinal septa on the inner surface of the compartment. However, MSNC 4562 differs markedly from P. decorata 
by exhibiting a thinner wall, a distinctly shorter sheath, sutural edges of the compartment that lack external ornamentation, and a different aspect of the outer wall (e.g., the shell of $P$. decorata is monolamellar, each compartment being externally ornamented by fine longitudinal columns). Moreover, the shell of $P$. decorata is more or less cylindrical - a feature different from MSNC 4562, which would best match a truncated conical shell morphology.

MSNC 4562 also resembles $\uparrow P$. wilsoni in exhibiting transverse grooves on the sheath and a basal inner margin of the compartment without septa. However, MSNC 4562 clearly differs from this Late Pleistocene species by having a $P$. hexastylos-like radius (rather than a hollow tube) and by a clearly different ornamentation of the external surface of the shell (e.g., the outer wall of $\dagger P$. wilsoni has a shingled appearance).

In conclusion, MSNC 4562 looks both structurally and morphologically more similar to the type species of the genus Platylepas (i.e., P. hexastylos) than to other congeners known to date (e.g., P. decorata). At the same time, MSNC 4562 significantly differs from all the species of Platylepas known to date, thus warranting the erection of a new species $-\uparrow P$. mediterranea sp. nov.

\section{Discussion}

Following previous literature sources (e.g., Gray 1825; Costa 1838; Darwin 1854; Chevreux \& de Guerne 1893; Gruvel 1912; Richard 1936; Kolosváry 1939, 1943; Pilleri 1970; Raga \& Carbonell 1985; Gramentz 1988; Pasternak et al. 2002; Kitsos et al. 2003, 2005; Casale et al. 2004; Bakır et al. 2010; Fuller et al. 2010; Karaa et al. 2011; Vallini et al. 2011), seven species of turtle and whale barnacles are known to occur in the present-day Mediterranean Sea: three, namely Chelonibia caretta (Spengler, 1790), Chelonibia testudinaria (Linnaeus, 1758) and Chelonibia patula (Ranzani, 1817), belong to Chelonibiidae; three, namely Platylepas coriacea, P. hexastylos and Stomatolepas elegans (Costa, 1838), to Platylepadidae; and a single one (Xenobalanus globicipitis Steenstrup, 1852) to Coronulidae. When fossil remains are taken into account, the picture changes considerably. The Mediterranean fossil record of coronuloid barnacles is marked by a predominance of whale barnacles that are represented by at least five species in three genera (Cetopirus Ranzani, 1817, Coronula Lamarck, 1802 and Tubicinella Lamarck, 1802) from various Upper Pliocene to Holocene deposits in Italy, Cyprus and Spain (e.g., Aradas 1854; Seguenza 1873; Simonelli 1893; De Alessandri 1895, 1906; De Gregorio 1895; Menesini 1968; Cipolla 1978; Bossio et al. 1993; Bianucci et al. 2006; Dominici et al. 2011; Álvarez-Fernández et al. 2014; Collareta 2016; Collareta et al. 2016b, 2018a, 2018b; Bosselaers et al. 2017). In the same broad region, fossil turtle barnacles are known to start occurring from the Miocene (Seguenza 1876; De Alessandri 1895, 1906; Withers 1929; Bianucci 1996; Harzhauser et al. 2011; Collareta et al. 2016a) but, up to now, they merely comprise a few Neogene occurrences of the chelonibiid genera Chelonibia Leach, 1817 and $\uparrow$ Protochelonibia Harzhauser \& Newman 2011 in Harzhauser et al., 2011. Therefore, MSNC 4562 represents the first occurrence of a fossil platylepadid in the Mediterranean Basin. Moreover, as far as we know, the global fossil record of Platylepadidae is confined to a single occurrence, namely that of $\uparrow P$. wilsoni in the Upper Pleistocene deposits of the Pamlico Formation of Florida (USA) (Ross 1963). Our record thus significantly extends downwards the stratigraphic range of Platylepas and, generally, that of the entire family, to the Gelasian (lowermost Pleistocene). It comes as some surprise that, in light of the rather conspicuous (albeit still scanty) fossil record of Chelonibia and Coronula, only two fossil occurrences of Platylepas on a global scale are known to date. As already evoked by Hayashi (2013), the paucity of members of this genus in the fossil record might be related to the fragile nature of its shell elements and the small size of its wall plates.

What kind of living substrate did the type specimen of $\uparrow P$. mediterranea sp. nov. attach to? So far, the verified hosts of extant Platylepas spp. include all living genera of sea turtles and sea cows, as well as several forms of sea snakes and a single genus of holostean fish, i.e., the North American gar, Lepisosteus 
Lacépède, 1803 (e.g., Darwin 1854; Lanchester 1902; Krüger 1912; Pilsbry 1916; Nilsson-Cantell 1938; Daniel 1958; Stubbings 1965; Utinomi 1970; Zann 1975; Zann \& Harker 1978; Monroe \& Limpus 1979; Young 1991; Hernández-Vázquez \& Valadez-González 1998; Jones 2004, 2010; Hayashi et al. 2011; Lazo-Wasem et al. 2011; Hayashi 2012). Lepisosteid gars and sea snakes have never been recorded from the Mediterranean region, either as living individuals or as fossil remains from Cenozoic strata. Sirenians are also absent from the present-day Mediterraean Sea; however, tens of fossil specimens are known from Paleogene and Neogene deposits, predating the latest Pliocene (ca $3 \mathrm{Ma}$; Sorbi et al. 2012). Having observed this, and also considering that the Italian Plio-Pleistocene record of sea turtles includes several fragmentary indeterminate cheloniids (Chesi \& Delfino 2006), we argue that MSNC 4562 might have been attached to a sea turtle. If this line of reasoning is correct, $\uparrow P$. mediterranea sp. nov. could be added to the list of chelonophilic coronuloid barnacles, to which most extant representatives of the genus Platylepas belong. As noted above, the external aspect of MSNC 4562 strongly recalls that of a specimen of $P$. hexastylos from Sicily illustrated by Pilsbry (1916: pl. 67, fig. 4). This specimen was briefly characterized by Pilsbry (1916: 287) as follows: "It has steep, convex sides, deep median clefts in the compartments, but the internal midribs are slender and project but little [...] The septa are very numerous, sharp, and close [...] From the appearance of this barnacle I suspect that it did not live on the shell of a turtle. There is some orange-coloured skin adhering in the furrows of the lower part of the parietes". Interestingly, the description and illustration of that particular specimen provided by Pilsbry (1916), inclusive of the presence of orange-colored shreds of the embedding tissue of its host, perfectly match the aspect of several truncated conical extant specimens of $P$. hexastylos recovered by one of us (G.I.) and partially embedded in the skin of a loggerhead turtle, i.e., Caretta caretta (Linnaeus, 1758), beached along the coast of Donnalucata (Ragusa, Sicily, Italy) on 25 July 2000. Personal observations by two of us (A.C. and G.I.) on platylepadid phoronts associated with this chelonian individual suggest that truncated conical individuals of $P$. hexastylos were preferentially found partially embedded in the skin of the turtle, whereas their peltate conspecifics might have been commoner on the carapace and plastron. More generally, within the genus Platylepas, depressed shell morphologies appear to prevail among those forms that tend to adhere superficially to a host (as observed for the typically peltate P. coriacea; see, e.g., Monroe \& Limpus 1979), whereas less flattened (up to cylindrical) shell shapes characterize those that manage to become anchored within a soft substrate (as observed for the typically ring-like $P$. decorata; see, e.g., Zardus \& Balasz 2007). Therefore, we suggest that MSNC 4562 lived partially embedded in the skin of a cheloniid sea turtle, as currently observed for many phenotypically similar individuals of $P$. hexastylos attaching to Caretta caretta in central Mediterranean waters.

Recent phylogenetic analyses (Hayashi et al. 2013; Pérez-Losada et al. 2014) agree in recognizing the genus Chelonibia as occupying a basal position within Coronuloidea, as had been proposed much earlier based simply on morphology (e.g., Foster 1979; Buckeridge 1983). Given the general lack of occurrences of fossil turtle barnacles other than chelonibiids prior to the Upper Pleistocene, some platylepadid genera have occasionally been regarded as Pleistocene or Recent offshoots of Coronulidae (Hayashi et al. 2013). However, morphological considerations discourage the acceptance of this hypothesis, suggesting instead that the extant genus Platylepas is a surviving member of an ancient group of generalist epizoic barnacles (Ross \& Newman 1967). According to the divergence time analysis by Hayashi et al. (2013), Platylepas originated during the Early or Middle Miocene. Although no fossil specimen of Platylepas is known from sedimentary deposits from this time interval, Hayashi et al. (2013) argued that a trace of a Platylepas-like barnacle could be detected on the carapace of a fossil sea turtle, i.e., the type specimen of "Euclastes" melii Misuri, 1910, from Miocene strata of the 'Pietra Leccese' (Apulia, southern Italy). Hayashi et al. (2013) based their claim on an illustration provided by Misuri (1910) in the paper in which "E." melii was described. Unfortunately, the whereabouts of the type material is currently unknown; the trace-bearing specimen illustrated by Misuri (1910) may have been lost (Chesi et al. 2007). Therefore, a direct analysis of the trace fossil hinted at by Hayashi et al. (2013) cannot be carried out, leaving their inference unconfirmed at this time. However, our discovery of a new species of Platylepas that is 
phenotypically close to extant $P$. hexastylos in deposits dated as Early Pleistocene may provide some support to a 'less shallow' evolutionary history for the epizoic barnacles currently grouped in the family Platylepadidae. Considering also the strongly biased nature of the fossil record of thin-walled, smallsized barnacles such as Platylepas spp., a Neogene origin of the platylepadid lineage would appear plausible.

\section{Concluding remarks}

As already evoked elsewhere (e.g., Seilacher 1992, 2005; Bianucci et al. 2006; Fertl 2009; Dominici et al. 2011; Hayashi et al. 2013; Pérez-Losada et al. 2014; Collareta et al. 2016a, 2016b, 2018a; Buckeridge et al. 2018), the extant epibiotic organisms included in the superfamily Coronuloidea are regarded as the ultimate product of an outstanding path of co-evolution with their vertebrate hosts. Nevertheless, the fossil record of coronuloid barnacles is still fragmentary and partially unexplored. As a consequence, the Cenozoic steps of such a co-evolutionary path are only vaguely known and largely speculative. The fossil occurrence of Platylepas recorded in the present paper adds new data to previous studies by extending back the fossil history of Platylepadidae to the lowermost Quaternary, thus supporting an earlier (e.g., Neogene) timing for the origin of this family and substantially contributing to our views of the evolutionary history of one of the most diverse and successful lineages of epizoic crustaceans. Further additions to the fossil record of coronuloid barnacles will certainly assist in illustrating how the "evolutionary dream" (sensu Seilacher 1992, 2005) of riding a whale or a sea turtle could have come true for an amazing lineage of tiny crustaceans.

\section{Acknowledgments}

We express our gratitude to Derek Ohland (Natural History Iziko South African Museum), Gianna Innocenti (Museo di Storia Naturale, Sezione di Zoologia "La Specola", Università degli Studi di Firenze), Chiara Sorbini (Museo di Storia Naturale dell'Università di Pisa), Yves Samyn and the late Frank Fiers (both Royal Belgian Institute of Natural Sciences, Brussels) for access to their coronuloid material and for the loan of specimens for comparative purposes. Alfio Viola (Università di Catania) is acknowledged for his help in the scanning electron microscope imaging of the specimen.

We are deeply indebted to John W.M. Jagt (Natuurhistorisch Museum Maastricht), John S. Buckeridge (RMIT University, Melbourne) and Christian de Muizon (Muséum national d'Histoire naturelle, Paris), whose constructive criticisms greatly improved an early version of the present paper.

\section{References}

Álvarez-Fernández E., Carriol R.P., Jordá J.F., Aura J.E., Avezuela B., Badal E., Carrión Y., GarcíaGuinea J., Maestro A., Morales J.V., Perez G., Perez-Ripoll M., Rodrigo M.J., Scarff J.E., Villalba M.P. \& Wood R. 2014. Occurrence of whale barnacles in Nerja Cave (Málaga, southern Spain): indirect evidence of whale consumption by humans in the Upper Magdalenian. Quaternary International 337: 163-169. https://doi.org/10.1016/j.quaint.2013.01.014

Aradas A. 1854. Monografia del genere Coronula e descrizione di alcune altre nuove specie di conchiglie siciliane. Atti dell'Accademia Gioenia di Scienze Naturali (Catania) 9: 57-72.

Bakır K., Özcan T. \& Katağan T. 2010. On the occurrence of Chelonibia patula (Cirripedia) on the coasts of Turkey. Marine Biodiversity Records 3: article \#e80.

Bianucci G. 1996. A new record of baleen whale from the Pliocene of Tuscany (Italy). Atti della Società Toscana di Scienza Naturali, Memorie (Serie A) 102: 101-104.

Bianucci G., Landini W. \& Buckeridge J. 2006. Whale barnacles and Neogene cetacean migration routes. New Zealand Journal of Geology and Geophysics 49: 115-120. 
Borghi E., Garilli V. \& Bonomo S. 2014. Plio-Pleistocene Mediterranean bathyal echinoids: evidence of adaptation to psychrospheric conditions and affinities with Atlantic assemblages. Palaeontologia Electronica 17: article \#17.3.44A.

Bosselaers M., Van Nieulande F. \& Collareta A. 2017. A new record of Cetopirus complanatus (Cirripedia: Coronulidae), an epibiont of right whales (Cetacea: Balaenidae: Eubalaena spp.), from a beach deposit of Mediterranean Spain. Atti della Società Toscana di Scienze Naturali, Memorie (Serie A) 124: 43-48. https://doi.org/10.2424/ASTSN.M.2017.17

Bossio A., Landini W., Mazzei R., Ragaini L., Salvatorini G. \& Varola A. 1993. I fossili pliocenici di Sant'Andrea. In: Seminario Scientifico-tecnologico di Lecce (ed.) Guida alle Escursioni, XII Convegno della Società Paleontologica Italiana: 69-77. Conte, Lecce.

Buckeridge J.S. 1983. The fossil barnacles (Cirripedia: Thoracica) of New Zealand and Australia. New Zealand Geological Survey, Paleontological Bulletin 50: 1-151.

Buckeridge J.S., Chan B.K. \& Lee S.W. 2018. Accumulations of fossils of the whale barnacle Coronula bifida Bronn, 1831 (Thoracica: Coronulidae) provides evidence of a Late Pliocene cetacean migration route through the Straits of Taiwan. Zoological Studies 57: article \#54.

https://doi.org/10.6620/ZS.2018.57-54

Casale P., Freggi D., Basso R. \& Argano R. 2004. Epibiotic barnacles and crabs as indicators of Caretta caretta distribution and movements in the Mediterranean Sea. Journal of the Marine Biological Association of the United Kingdom 84: 1005-1006. https://doi.org/10.1017/S0025315404010318h

Chesi F. \& Delfino M. 2006. The Italian fossil record of the sea turtles. In: Bologna M.A., Capula M., Carpaneto G.M., Luiselli L., Marangoni C. \& Venchi A. (eds) Atti VI Congresso Nazionale della Societas Herpetologica Italica (Roma, 27 settembre-1 ottobre 2006): 95-116. Belvedere, Roma.

Chesi F., Delfino M., Varola A. \& Rook L. 2007. Fossil sea turtles (Chelonii, Dermochelyidae and Cheloniidae) from the Miocene of Pietra Leccese (late Burdigalian-early Messinian), Southern Italy. Geodiversitas 29: 321-333.

Chevreux E. \& de Guerne J. 1893. Crustacés et cirrhipèdes commensaux des tortues marines de la Méditerranée. Comptes Rendus hebdomadaires des Séances de l'Académie des Sciences (Paris) 116: $443-445$.

Cipolla P. 1978. Macrofauna del Pleistocene inferiore di Cinisi (Sicilia). Il Naturalista Siciliano (Serie IV) 2: 55-67.

Collareta A. 2016. Fossil turtle and whale barnacles (Crustacea: Cirripedia: Coronuloidea) kept at the Museo di Storia Naturale dell'Università di Pisa: an annotated catalogue. Atti della Società Toscana di Scienze Naturali, Memorie (Serie A) 123: 41-45. https://doi.org/10.2424/ASTSN.M.2016.18

Collareta A., Bosselaers M. \& Bianucci G. 2016a. Jumping from turtles to whales: a Pliocene fossil record depicts an ancient dispersal of Chelonibia on mysticetes. Rivista Italiana di Paleontologia e Stratigrafia 122: 35-44. https://doi.org/10.13130/2039-4942/7229

Collareta A., Margiotta S., Varola A., Catanzariti R., Bosselaers M. \& Bianucci G. 2016b. A new whale barnacle from the early Pleistocene of Italy suggests an ancient right whale breeding ground in the Mediterranean. Comptes Rendus Palevol 15: 473-481. https://doi.org/10.1016/j.crpv.2015.10.006

Collareta A., Insacco G., Reitano A., Catanzariti R., Bosselaers M., Montes M. \& Bianucci G. $2018 \mathrm{a}$. Fossil whale barnacles from the early Pleistocene of Sicily shed light on the coeval Mediterranean cetacean fauna. Carnets de Géologie 18: 9-22. https://doi.org/10.4267/2042/65747

Collareta A., Regattieri E., Zanchetta G., Lambert O., Catanzariti R., Bosselaers M., Covelo P., Varola A. \& Bianucci G. 2018b. New insights on ancient cetacean movement patterns from oxygen- 
isotope analyses of a Mediterranean Pleistocene whale barnacle. Neues Jahrbuch für Geologie und Paläontologie - Abhandlungen 288: 143-159. https://doi.org/10.1127/njgpa/2018/0729

Costa O.G. 1838. Di alcuni Balanidi appartenenti al Regno di Napoli. Atti dell'Accademia delle Scienze di Napoli 5: 1-117.

Daniel A. 1958. On Platylepas indicus n. sp. a new barnacle from the Madras coast of India. Annals and Magazine of Natural History (Series 13) 1: 755-757. https://doi.org/10.1080/00222935808651151

Darwin C. 1854. A Monograph on the Subclass Cirripedia with Figures of all the Species. The Balanidae, The Verrucidae, etc. Ray Society, London. https://doi.org/10.5962/bhl.title.2104

De Alessandri G. 1895. Contribuzione allo studio dei Cirripedi fossili d'Italia. Bollettino della Società Geologica Italiana 13: 234-314.

De Alessandri G. 1906. Studi monografici sui cirripedi fossili d'Italia. Palaeontographia Italica 12: 207-324.

De Gregorio A. 1895. Note sur un astéride et un cirripède du post-Pliocène de Sicile des genres Astrogonium et Coronula. Annali di Geologia e Paleontologia di Palermo 17: 1-7.

Dominici S., Bartalini M., Benvenuti M. \& Balestra B. 2011. Large kings with small crowns: a Mediterranean Pleistocene whale barnacle. Bollettino della Società Paleontologica Italiana 50: 95-101.

Fertl D. 2009. Barnacles. In: Perrin W.F., Wursig B. \& Thewissen J.G.M. (eds) Encyclopedia of Marine Mammals: 75-78. Academic Press, San Diego.

Fois E. 1990a. La successione neogenica di Capo Milazzo (Sicilia nord-orientale). Rivista Italiana di Paleontologia e Stratigrafia 95: 397-440.

Fois E. 1990b. Stratigraphy and palaeogeography of the Capo Milazzo area (NE Sicily, Italy): clues to the evolution of the southern margin of the Tyrrhenian Basin during the Neogene. Palaeogeography, Palaeoclimatology, Palaeoecology 78: 87-108. https://doi.org/10.1016/0031-0182(90)90206-M

Foster B.A. 1979. The Marine Fauna of New Zealand: Barnacles (Cirripedia: Thoracica). New Zealand Oceanographic Institute Memoir 69: 1-160.

Fuller W.J., Broderick A.C., Enever R., Thorne P. \& Godley B.J. 2010. Motile homes: a comparison of the spatial distribution of epibiont communities on Mediterranean sea turtles. Journal of Natural History 44: 1743-1753. https://doi.org/10.1080/00222931003624820

Gaetani M. 1986. Brachiopod palaeocommunities from the Plio/Pleistocene of Calabria and Sicily (Italy). In: Racheboeuf P.F. \& Emig C.C. (eds) Les Brachiopodes fossiles et actuels. Biostratigraphie du Paléozö̈que 4: 477-483.

Gaetani M. \& Saccà D. 1984. Brachiopodi batiali del Pliocene e del Pleistocene di Sicilia e Calabria. Rivista Italiana di Paleontologia e Stratigrafia 90: 407-458.

Gignoux M. 1913. Les formations marines pliocènes et quaternaires de l'Italie du sud et de la Sicilie. Annales de l'Université de Lyon 36: 1-693.

Gramentz D. 1988. Prevalent epibiont sites on Caretta caretta in the Mediterranean Sea. Il Naturalista Siciliano 12: 33-46.

Gray J.E. 1825. A synopsis of the genera of Cirripedes arranged in natural families, with a description of some new species. Annals of Philosophy (New Series) 10: 97-107.

Gruvel J.A. 1912. Mission Gruvel sur la côte occidentale d'Afrique (1909-1910) et collection du Muséum d'Histoire naturelle. Les Cirrhipèdes. Bulletin du Muséum national d'Histoire naturelle 18: 344-350. 
Harzhauser M., Newman W.A. \& Grunert P. 2011. A new Early Miocene barnacle lineage and the roots of sea-turtle fouling Chelonibiidae (Cirripedia, Balanomorpha). Journal of Systematic Palaeontology 9: 473-480. https://doi.org/10.1080/14772019.2010.528053

Hayashi R. 2012. Atlas of the barnacles on marine vertebrates in Japanese waters including taxonomic review of superfamily Coronuloidea (Cirripedia: Thoracica). Journal of the Marine Biological Association of the United Kingdom 92: 107-127. https://doi.org/10.1017/S0025315411000737

Hayashi R. 2013. A checklist of turtle and whale barnacles (Cirripedia: Thoracica: Coronuloidea). Journal of the Marine Biological Association of the United Kingdom 93: 143-182.

https://doi.org/10.1017/S0025315412000847

Hayashi R., Takuma S., Narazaki T. \& Sato K. 2011. Chelonia mydas agassizii (Black [Pacific] sea turtle). Epibiont barnacles. Herpetological Review 42: 264-265.

Hayashi R., Chan B.K., Simon-Blecher N., Watanabe H., Guy-Haim T., Yonezawa T., Levy Y., Shuto T. \& Achituv Y. 2013. Phylogenetic position and evolutionary history of the turtle and whale barnacles (Cirripedia: Balanomorpha: Coronuloidea). Molecular Phylogenetics and Evolution 67: 9-14. https://doi.org/10.1016/j.ympev.2012.12.018

Hernández-Vázquez S. \& Valadez-González C. 1998. Observaciones de los epizoarios encontrados sobre la tortuga golfina Lepidochelys olivacea en La Gloria, Jalisco, México. Ciencias Marinas 24: $119-125$.

Jones D.S. 2004. Barnacles (Cirripedia: Thoracica) of the Dampier Archipelago, Western Australia. Records of the Western Australian Museum, Supplement 66: 121-157.

Jones D.S. 2010. The littoral and shallow-water barnacles (Crustacea: Cirripedia) of south-eastern Queensland. In: Davie P.J.F. \& Phillips J.A. (eds) Proceedings of the Thirteenth International Marine Biological Workshop, The Marine Fauna and Flora of Moreton Bay, Queensland. Memoirs of the Queensland Museum-Nature 54: 199-233.

Karaa S., Insacco G., Bradai M.N. \& Scaravelli D. 2011. Records of Xenobalanus globicipitis on Balaenoptera physalus and Stenella coeruleoalba in Tunisian and Sicilian waters. Natura Rerum 1: $55-59$.

Kitsos M.S., Christodoulou M., Kalpakis S. \& Noidou M. 2003. Cirripedia Thoracica associated with Caretta caretta (Linnaeus, 1758) in the northern Aegean Sea. Crustaceana 76: 403-409.

https://doi.org/10.1163/156854003322033816

Kitsos M.S., Christodoulou M., Arvanitidis C., Mavidis M., Kirmitzoglou I. \& Koukouras A. 2005. Composition of the organismic assemblage associated with Caretta caretta. Journal of the Marine Biological Association of the United Kingdom 85: 257-261. https://doi.org/10.1017/S0025315405011136h

Kolosváry G. 1939. Über Fundortsangaben adriatischer Balanen. Bollettino dei Musei di Zoologia ed Anatomia Comparata della Regia Università di Torino (Serie 3) 47: 37-41.

Kolosváry G. 1943. Cirripedia Thoracica in der Sammlung des Ungarischen National-Museums. Annales Historico-Naturales Musei Nationalis Hungarici 36: 67-120.

Krüger P. 1912. Über einige interessante Vertreter der Cirripedia Thoracica. In: Döflein F. \& Bayer K. (eds) Beiträge zur Naturgeschichte Ostasiens. Abhandlungen der Mathematisch-Physikalische Klasse der Königlich Bayerischen Akademie der Wissenschaften II. Supplement Band 8: 9-16.

Lanchester W.F. 1902. On the Crustacea collected during the 'Skeat Expedition' to the Malay Peninsula. Proceedings of the Zoological Society of London 2: 363-381.

https://doi.org/10.1111/j.1469-7998.1902.tb08187.x 
Langer M. 1989. Haftorgan, Internodien und Sklerite von Keratoisis melitensis (Goldfuss, 1826) (Octocorallia) in den pliozänen Foraminiferenmegeln («Trubi») von Milazzo (Sizilien). Paläontologische Zeitschrift 63: 15-24. https://doi.org/10.1007/BF02989523

Lazo-Wasem E.A., Pinou T., de Niz A.P. \& Feuerstein A. 2011. Epibionts associated with the nesting marine turtles Lepidochelys olivacea and Chelonia mydas in Jalisco, Mexico: a review and field guide. Bulletin of the Peabody Museum of Natural History 52: 221-240.

Lipparini T., Malatesta A., Nicosia M. \& Valdinucci A. 1955. Pliocene e Quaternario del Capo Milazzo in Sicilia. Bollettino del Servizio Geologico Italiano 77: 579-604.

Marquet R., Collins J., Jagt J. \& van Bakel B. 2009. The invertebrate fauna of the Pliocene in Belgium. Part I. Annelida, Anthozoa and Crustacea. Palaeofocus 2: 41-61.

Mars P. 1956. Faunes malacologiques du Pliocène et du Quaternaire de Milazzo (Sicile). Bulletin du Muséum d'Histoire naturelle de Marseille 16: 33-52.

Menesini E. 1968. Osservazioni su Coronula bifida Bronn. Atti della Società Toscana di Scienze Naturali, Memorie (Serie A) 75: 387-398.

Misuri A. 1910. Sopra un nuovo chelonio del calcare miocenico di Lecce (Euclastes melii Misuri). Palaeontographia Italica 16: 119-136.

Monroe R. \& Limpus C.J. 1979. Barnacles on turtles in Queensland waters with descriptions of three new species. Memoirs of the Queensland Museum 19: 197-223.

Nilsson-Cantell C.A. 1938. Cirripedes from the Indian Ocean in the collection of the Indian Museum, Calcutta. Memoirs of the Indian Museum 13: 1-81.

Palazzi S. \& Villari A. 1996. Malacofaune batiali plio-pleistoceniche del Messinese. 2: Capo Milazzo. Il Naturalista Siciliano 20: 237-279.

Pasini G. \& Garassino A. 2011. Anapagurus mamertinus n. sp. (Anomura, Paguroidea, Paguridae) from the Pliocene of S. Antonio, Capo Milazzo (Sicily, S Italy). Natural History Sciences 152: 57-62.

Pasternak Z., Abelson A. \& Achituv Y. 2002. Orientation of Chelonibia patula (Crustacea: Cirripedia) on the carapace of its crab host is determined by the feeding mechanism of the adult barnacles. Journal of the Marine Biological Association of the United Kingdom 82: 583-588.

https://doi.org/10.1017/S002531540200591X

Pérez-Losada M., Høeg J.T., Simon-Blecher N., Achituv Y., Jones D. \& Crandall K.A. 2014. Molecular phylogeny, systematics and morphological evolution of the acorn barnacles (Thoracica: Sessilia: Balanomorpha). Molecular Phylogenetics and Evolution 81: 147-158.

https://doi.org/10.1016/j.ympev.2014.09.013

Pilleri G. 1970. Xenobalanus globicipitis Steenstrup on Delphinus delphis, Stenella styx and Tursiops truncatus of the western Mediterranean. Investigations on Cetacea 2: 248-249.

Pilsbry H.A. 1916. The sessile barnacles (Cirripedia) contained in the collections of the U.S. National Museum; including a monograph of the American species. Bulletin of the United States National Museum 93: 1-366.

Raga J.A. \& Carbonell E. 1985. New data about parasites on Stenella coeruleoalba (Meyen, 1833) (Cetacea: Delphinidae) in the western Mediterranean Sea. Investigations on Cetacea 17: 207-213.

Richard J. 1936. Documents sur les cétacés et pinnipèdes provenant des Campagnes du Prince Albert $1^{\text {er }}$ de Monaco. Résultats des Campagnes scientifiques 94: 1-71.

Ross A. 1963. A new Pleistocene Platylepas from Florida. Quarterly Journal of the Florida Academy of Science 26: 150-158. 
Ross A. \& Frick M.G. 2011. Nomenclatural emendations of the family-group names Cylindrolepadinae, Stomatolepadinae, Chelolepadinae, Cryptolepadinae, and Tubicinellinae of Ross \& Frick, 2007including current definitions of family-groups within the Coronuloidea (Cirripedia: Balanomorpha). Zootaxa 3106: 60-66.

Ross A. \& Newman W.A. 1967. Eocene Balanidae of Florida, including a new genus and species with a unique plan of "turtle-barnacle" organization. American Museum Novitates 2288: 1-21.

Rosso A. 2002a. Bryobaculum carinatum gen. et sp. nov.: a new Mediterranean Pliocene deep-water bryozoan. In: Wyse Jackson P.N., Buttler C.J. \& Spencer Jones M.E. (eds) Bryozoan Studies 2001 Proceedings of the $12^{\text {th }}$ International Bryozoology Association Conference, Dublin, Ireland, 16-21 July 2001: 275-283. Balkema Publishers, Lisse, the Netherlands.

Rosso A. 2002b. Terataulopocella borealis gen. et sp. nov., a deep-water Pliocene lekythoporid (Bryozoa) from the Mediterranean Area. Memorie di Scienze Geologiche 54: 65-72.

Rosso A. 2005. Metrarabdotos (Bryozoa, Cheilostomatida) from the Plio-Pleistocene of southern Italy, with description of new species. Bollettino della Società Paleontologica Italiana 44: 11-24.

Rosso A. \& Braga G. 2013. The genus Sparsiporina d'Orbigny, 1852 (Bryozoa, Cheilostomata): Late Eocene to Holocene. In: Ernst A., Schäfer P. \& Scholz J. (eds) Bryozoan Studies 2010: 271-287. Springer, Berlin/Heidelberg.

Rosso A. \& Di Martino E. 2015. Myriapora sciutoi n. sp., a new fossil Atlanto-Mediterranean bryozoan species, and comments on allied taxa. Rivista Italiana di Paleontologia e Stratigrafia 121: 369-379.

Rosso A., Sanfilippo R., Di Geronimo I., Bonfiglio L., Sineo L., Sciuto F., Violanti D., Vertino A. \& Mangano G. 2012. Giornate di Paleontologia, XII Edizione, Paleodays 2012. Libro guida all'Escursione. Acquedolci e Capo Milazzo (ME). Tipografia dell’Università, Catania.

Sciuto F. 2003. Dati preliminari sulla ostracofauna pliocenica di Capo Milazzo (Sicilia NE). Bollettino della Società Paleontologica Italiana 42: 179-184.

Sciuto F. 2005. Ostracodi batiali pleistocenici di Capo Milazzo (Sicilia NE) ed implicazioni paleoambientali. Rendiconti della Società Paleontologica Italiana 2: 219-227.

Sciuto F. 2009. Bythocythere mylaensis n. sp. (Crustacea, Ostracoda) from Early Pleistocene of Capo Milazzo (NE Sicily). Bollettino della Società Paleontologica Italiana 48: 183-188.

Sciuto F. 2012a. New ostracod species from Lower Pleistocene bathyal sediments of Capo Milazzo (NE, Sicily). Bollettino della Società Paleontologica Italiana 51: 117-125.

Sciuto F. 2012b. Bythocythere solisdeus n. sp. and Cytheropteron eleonorae n. sp. (Crustacea, Ostracoda) from the Early Pleistocene bathyal sediments of Cape Milazzo (NE, Sicily). Geosciences (Basel) 2: 147-156. https://doi.org/10.3390/geosciences2030147

Sciuto F. 2014. Ostracods of the Upper Pliocene-Pleistocene Punta Mazza succession (NE Sicily) with special focus on the Family Trachyleberididae Sylvester-Bradley, 1948, and description of a new species. Carnets de Géologie 14: 1-13.

Seguenza G. 1873-1876. Ricerche paleontologiche intorno ai Cirripedi terziari della provincia di Messina. Con appendice intorno ai Cirripedi viventi nel Mediterraneo e sui fossili terziari dell'Italia Meridionale. Parte I [1873] + Parte II [1876]. Atti dell'Accademia Pontaniana 10: 267-481.

Seilacher A. 1992. Whale barnacles: how an evolutionary dream could become true. Mitteilungen des Sonderforschungsbereichs 230: 131-136.

Seilacher A. 2005. Whale barnacles: exaptational access to a forbidden paradise. Paleobiology 31 (Supplement): 27-35. https://doi.org/10.1666/0094-8373(2005)031[0027:WBEATA]2.0.CO;2 
Simonelli V. 1893. Fossili terziari e postpliocenici dell'Isola di Cipro. Memorie della Reale Accademia delle Scienze dell'Istituto di Bologna (Serie V) 3: 353-362.

Sorbi S., Domning D.P., Vaiani S.C. \& Bianucci G. 2012. Metaxytherium subapenninum (Bruno, 1839) (Mammalia, Dugongidae), the latest sirenian of the Mediterranean basin. Journal of Vertebrate Paleontology 32: 686-707. https://doi.org/10.1080/02724634.2012.659100

Stubbings H.G. 1965. West African Cirripedia in the collections of the Institut Français d'Afrique Noire, Dakar, Senegal. Bulletin de l'Institut français d'Afrique noire (Series A) 27: 876-907.

Utinomi H. 1970. Studies on the cirripedian fauna of Japan. IX. Distributional survey of thoracic cirripeds in the southeastern part of Japan Sea. Publications of the Seto Marine Biological Laboratory 17: 339-372.

Vallini C., Rubini S., Tarricone L., Mazziotti C. \& Gaspari S. 2011. Unusual stranding of live, small, debilitated loggerhead turtles along the northwestern Adriatic coast. Marine Turtle Newsletter 131: 2528.

Violanti D. 1988. I foraminiferi plio-pleistocenici di Capo Milazzo. Bollettino del Museo Regionale di Scienze Naturali di Torino 6: 359-392.

Withers T.H. 1929. The cirripede Chelonibia in the Miocene of Gironde, France and Vienna, Austria. Annals and Magazine of Natural History (Series 10) 4 (24): 566-569. https://doi.org/10.1080/00222932908673099

Young P.S. 1991. The superfamily Coronuloidea Leach (Cirripedia, Balanomorpha) from the Brazilian coast, with redescription of Stomatolepas species. Crustaceana 61: 190-212.

https://doi.org/10.1163/156854091X00678

Zann L.P. 1975. Biology of a barnacle (Platylepas ophiophilus Lanchester) symbiotic with sea snakes. In: Dunson W.A. (ed.) The biology of sea snakes: 267-286. University Park Press, Baltimore.

Zann L.P. \& Harker B.M. 1978. Egg production of the barnacles Platylepas ophiophilus Lanchester, Platylepas hexastylos (O. Fabricius), Octolasmis warwickii Gray and Lepas anatifera Linnaeus. Crustaceana 35: 206-214.

Zardus J.D. \& Balazs G.H. 2007. Two previously unreported barnacles commensal with the green sea turtle, Chelonia mydas (Linnaeus, 1758), in Hawaii and a comparison of their attachment modes. Crustaceana 80: 1303-1315. https://doi.org/10.1163/156854007782605547

Manuscript received: 23 November 2018

Manuscript accepted: 10 January 2019

Published on: 16 April 2019

Topic editor: Christian de Muizon

Desk editor: Kristiaan Hoedemakers

Printed versions of all papers are also deposited in the libraries of the institutes that are members of the EJT consortium: Muséum national d'Histoire naturelle, Paris, France; Meise Botanic Garden, Belgium; Royal Museum for Central Africa, Tervuren, Belgium; Royal Belgian Institute of Natural Sciences, Brussels, Belgium; Natural History Museum of Denmark, Copenhagen, Denmark; Naturalis Biodiversity Center, Leiden, the Netherlands; Museo Nacional de Ciencias Naturales-CSIC, Madrid, Spain; Real Jardín Botánico de Madrid CSIC, Spain; Zoological Research Museum Alexander Koenig, Bonn, Germany. 